\title{
Alteration of compacted GMZ bentonite by infiltration of alkaline solution
}

\author{
CHEN BAO ${ }^{1, *}$, GUO JIAXING ${ }^{1}$ AND ZHANG HUIXIN ${ }^{2}$ \\ ${ }^{1}$ Key Laboratory of Geotechnical and Underground Engineering of Ministry of Education, Tongji University, Shanghai \\ 200092, China \\ ${ }^{2}$ Shanghai Construction Design \& Research Institute Co., Ltd., Shanghai 200050, China
}

(Received 31 May 2015; revised 4 April 2016; Guest editor: Reiner Dohrmann)

\begin{abstract}
Concepts for geological disposal of high-level radioactive waste usually include bentonite buffer materials. Numerous studies have been performed with most using Wyoming bentonite. Gaomiaozi (GMZ) bentonite has been selected as a potential buffer/backfill material for the deep geological repository of high-level radioactive waste in China. In this context, the highly alkaline environment induced by cementitious materials in the repository is likely to alter montmorillonite, the main clay mineral in GMZ bentonite. This alteration may result in deterioration of the physical and/or chemical properties of the buffer material. To acquire quantitative data which would allow us to assess the dissolution of montmorillonite and changes in the diffusivity of hydroxide ions as well as their effects on the swelling pressure and permeability of the compacted GMZ bentonite, an experimental study was conducted under highly alkaline $(\mathrm{NaOH}$ solutions with various $\mathrm{pH}$ values were used), simulated groundwater conditions. The GMZ bentonite also contains cristobalite which may also have been dissolved. The microstructure of the compacted bentonite samples after the experiments was determined by mercury intrusion porosimetry (MIP) and scanning electron microscopy (SEM). Energy dispersive spectroscopy (EDX) was carried out to identify mineralogical changes. At $\mathrm{pH}>13$, the permeability of specimens increased significantly; the swelling potential decreased with increasing $\mathrm{pH}$. Furthermore, the pore volume and pore size of GMZ bentonite changed when exposed to alkaline solution, resulting in an increase in porosity and permeability. The main alteration mechanisms of compacted GMZ bentonite undergoing infiltration by highly alkaline solution are likely to be dissolution and modifications in terms of the microstructure and mineralogy.
\end{abstract}

KEYWORDS: GMZ bentonite, highly alkaline solution, swelling pressure, permeability, microstructure.

In recent decades, numerous experimental and numerical investigations have been conducted to evaluate the behaviour of clay barriers in Deep Geological Repositories (DGR) for the disposal of high-level radioactive waste (HLRW). One of the main concerns of these investigations is the mineralogical changes that are expected to occur in the engineering barrier system during the long life of a waste repository (tens of thousands of years). Indeed, in practice, in many

*E-mail: chenbao@tongji.edu.cn

DOI: $10.1180 /$ claymin.2016.051.2.10 potential host-rock formations it is necessary to build a concrete ring between the geological barrier and the bentonite barrier/plug that serves as a structure support. During the long-term operation of the repository, the concrete components will decay, producing alkaline fluids with a $\mathrm{pH}>12$. The highly alkaline solution may react with the bentonite near the concrete, inducing dissolution and the alteration of the physical and chemical properties of bentonite (Glasser \& McCulloch, 1988; Anderson et al., 1989; Berner, 1992; Savage et al., 2007; Deneele et al., 2010). Using a highly alkaline solution $(\mathrm{NaOH}, \mathrm{pH} 14)$, Nakayama et al. (2004) showed an increase in porosity and 
permeability of a compacted bentonite. Montmorillonite dissolution was also expected to occur over two stages: (1) a short-term (initial) stage $(\mathrm{pH}>13)$, characterized by alkaline dissolution of montmorillonite and the formation of $\mathrm{Na} / \mathrm{K}$-zeolites and trioctahedral $\mathrm{Mg}$-smectite (Vigil et al., 2001; Ramírez et al., 2002, 2005; Sánchez et al., 2006); and (2) a long-term stage $(\mathrm{pH} \approx 12.5)$ of portlandite dissolution equilibrium, characterized by the formation of CSH gels and trioctahedral $(\mathrm{Mg})$ clay minerals in the concrete-clay interface (Read et al., 2001; Ramírez et al., 2002; Savage et al., 2002).

Various studies have shown that the bentonite swelling capacity is affected by highly alkaline pore water and permeability increases, due to the increase in cation concentration (Karnland et al., 2007; Lehikoinen et al., 1996; Yamaguchi et al., 2007; Cuisinier et al., 2008).

The alteration of bentonite in contact with alkaline solutions was also investigated through microstructure studies. Studies using mercury intrusion porosimetry (MIP) and scanning electron microscopy (SEM), showed that the number of large pores and total porosity of bentonite specimens increased significantly with circulation of the alkaline solution $\left(\mathrm{Ca}(\mathrm{OH})_{2}\right)$ (Cuisinier et al., 2008; Deneele et al., 2010). Through SEM images, Karnland et al. (2007) reported that the microstructures of bentonite specimens before and after contact with $1.0 \mathrm{~mol} / \mathrm{L} \mathrm{NaOH}$ solution for several months were significantly different. After reaction of MX-80 bentonite with solutions of different ionic concentrations and $\mathrm{pH}$ values for $3 \mathrm{y}$ the montmorillonite particles maintained their full expandability to ethylene glycol (Herbert et al., 2008). Nevertheless, significant alteration of montmorillonite was identified by transmission electron microscopy (TEM). After reaction in different solutions, all smectite particles were transformed from an initial film-like matrix of a very thin platy shape to a discrete well-oriented platy shape. Several studies reported the dissolution of montmorillonite and an increase in the total porosity in a synthetic alkaline groundwater environment (Lehikoinen et al., 1996; Nakayama et al., 2004; Sánchez et al., 2006; Karnland et al., 2007; Yamaguchi et al., 2007; Cuisinier et al., 2008; Deneele et al., 2010). These laboratory studies did not resolve the question of whether such reactions would also occur in a real HLRW storage system affecting the buffering and isolation performance of bentonite. On the other hand Karnland et al. (2007) also observed a two-stage dissolution of a Wyoming bentonite because this bentonite contains cristobalite which is known to be unstable in high-pH conditions. Karnland et al. (2007) attributed the initial part of this response pattern to cristobalite dissolution, and the latter part to dissolution of montmorillonite and quartz, when all the cristobalite has been consumed.

In China, Gaomiaozi (GMZ) bentonite has been selected as a potential buffer/backfill material for the deep geological repository for high-level nuclear waste disposal (Ye et al., 2009) mainly due to the large montmorillonite content ( $75 \mathrm{wt} . \%$ ). The basic physical and chemical properties, mineralogical composition, and hydraulic and mechanical properties of GMZ bentonite have been investigated widely (Liu \& Wen, 2003; Qian, 2007; Ye et al., 2009, 2010). However, only limited information on the alkaline alteration of GMZ bentonite is available.

\section{MATERIALS AND METHODS}

The swelling pressure and saturated hydraulic conductivity of the GMZ bentonite was determined using a self-developed swelling-permeameter. Mercury intrusion porosimetry and SEM were used to investigate changes in the microstructure of the bentonite.

\section{Material}

The GMZ bentonite tested is a Na-bentonite, obtained from Gaomiaozi bentonite deposit in Xinghe County, Inner Mongolia, China. The basic physical and chemical properties of the GMZ bentonite are listed in Table 1 (Wen, 2006). In general, GMZ bentonite has a moderately high CEC and is free of soluble Ca minerals such as carbonates or gypsum.

\section{Experimental setup}

A multi-functional swelling-permeameter was employed in the present study and the experimental setup is shown in Fig. 1: it consists of a basement, a specimen ring, two porous stones, a stainless-steel piston, a pressure sensor and an upper steel sleeve. A Pressure \& Volume Controller (PVC) was used to apply pressure and measure the volume of liquid injected. For the infiltration tests with alkaline solutions, an acrylic conversion device was designed to avoid direct contact between the salt solution and the PVC. In this device, light silicone oil was used as a separation layer between the water and alkaline solution.

Considering that the GMZ bentonite is a Nabentonite and that the main cation in the groundwater 
TABLE 1. Basic physico-chemical properties of GMZ bentonite (reproduced from Wen, 2006, with the author's permission).

\begin{tabular}{ll}
\hline Parameter & Value \\
\hline $\begin{array}{l}\text { Specific gravity } \mathrm{G}_{\mathrm{s}} \\
\left(\mathrm{mg} / \mathrm{m}^{3}\right)\end{array}$ & 2.66 \\
$\mathrm{pH}$ & $8.68 \sim 9.86$ \\
Liquid limit (\%) & 276 \\
Plastic limit (\%) & 37 \\
Total specific surface area & 570 \\
$\left(\mathrm{~m}^{2} \cdot \mathrm{g}^{-1}\right)$ & \\
Main exchange ion & $\mathrm{Na}^{+}(43.36), \mathrm{Ca}^{2+}(14.57)$, \\
content (meq/100 g) & $\mathrm{Mg}^{2+}(6.17), \mathrm{K}^{+}(2.51)$ \\
Main mineral content & $\mathrm{Montmorillonite}(75 \%)$, \\
& Quartz $(12 \%), F e l d s p a r$ \\
& $(4 \%)$, Cristobalite $(7 \%)$
\end{tabular}

in Beishan (potential site for Chinese nuclear waste repository) is $\mathrm{Na}^{+}$(Guo et al., 2005), $\mathrm{NaOH}$ solutions with concentrations of $0.1,0.3$ and $0.6 \mathrm{~mol} / \mathrm{L}$ were chosen for the infiltration tests.

\section{Preparation of specimens}

The GMZ bentonite powder was compacted using a special stainless-steel mould to prepare specimens $50 \mathrm{~mm}$ in diameter and $10 \mathrm{~mm}$ tall, at different initial dry densities: $1.50,1.60$ and $1.70 \mathrm{Mg} / \mathrm{m}^{3}$. The vertical load was applied using a digital loading frame $(300 \mathrm{kN}$, type CSS-44300) at a rate of $0.1 \mathrm{~mm} / \mathrm{min}$. After compaction, the specimens were unloaded and introduced into the swelling permeameter for testing (Fig. 1).

Twelve tests were performed on specimens at different initial dry densities and different $\mathrm{NaOH}$ concentrations. The specimens tested and the corresponding solutions used are shown in Table 2.

\section{Testing process}

In the tests, the two valves in the permeameter were opened and the solution was injected through a valve. After the air bubbles in the testing system were exhausted, valve 1 at the bottom and valve 2 at the top were closed. Then, the alkaline solution was injected in steps of $1 \mathrm{kPa}$ up to $1 \mathrm{MPa}$. All tests were run at ambient temperature $\left(20^{\circ} \mathrm{C}\right)$.

The injection pressure was applied in steps of $1 \mathrm{kPa} / \mathrm{min}$. The flow rate of the solution and the swelling pressure of the bentonite were monitored. During the test, the water volume increased rapidly after each step of pressure application and became steady, suggesting a full saturation of the specimen. The swelling pressure corresponding to this steady state is considered to be the final swelling pressure of the specimen.

Based on the flow rate recorded, the hydraulic conductivity was calculated using Darcy's law, as follows:

$$
k=\frac{\Delta Q \cdot L}{A\left(h_{1}-h_{2}\right) \Delta t}
$$

where $L$ is the height of the specimen (cm), $A$ is the cross-section area $\left(\mathrm{cm}^{2}\right),\left(h_{1}-h_{2}\right)$ is the water head

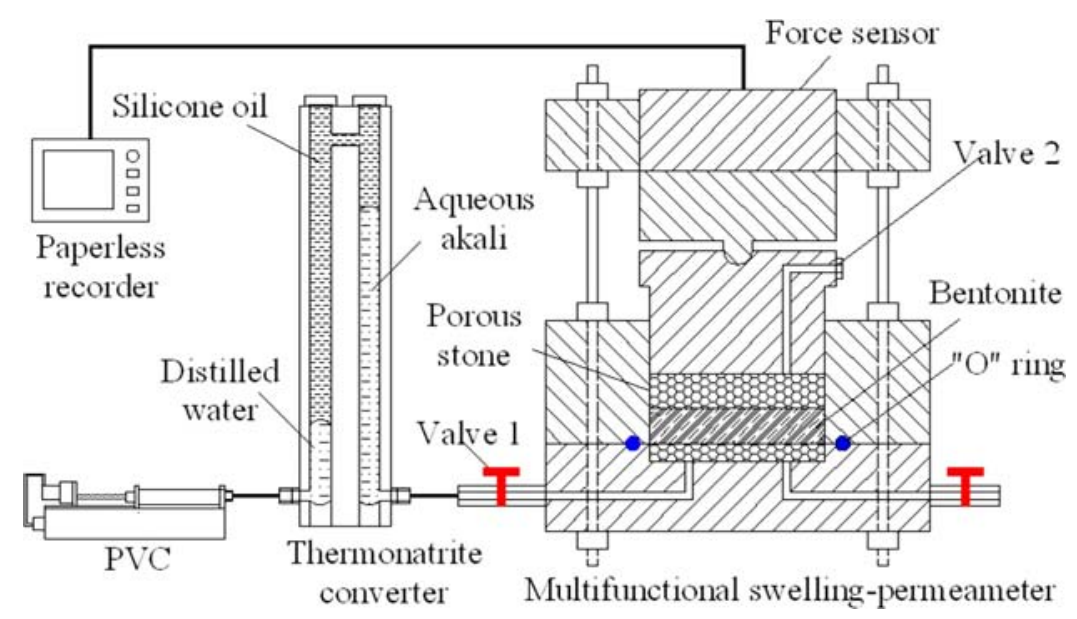

FIG. 1. Experimental set-up for infiltration testing. 
TABLE 2. Samples tested and concentrations and $\mathrm{pH}$ of the solutions used.

\begin{tabular}{llll}
\hline No. & $\begin{array}{l}\text { Dry density } \\
\left(\mathrm{mg} / \mathrm{m}^{3}\right)\end{array}$ & Solution & $\mathrm{pH}$ \\
\hline 1 & 1.70 & Distilled water & 7.0 \\
2 & & $0.1 \mathrm{~mol} / \mathrm{L} \mathrm{NaOH}$ & 13.0 \\
3 & & $0.3 \mathrm{~mol} / \mathrm{L} \mathrm{NaOH}$ & 13.5 \\
4 & & $0.6 \mathrm{~mol} / \mathrm{L} \mathrm{NaOH}$ & 13.8 \\
5 & 1.60 & Distilled water & 7.0 \\
6 & & $0.1 \mathrm{~mol} / \mathrm{L} \mathrm{NaOH}$ & 13.0 \\
7 & & $0.3 \mathrm{~mol} / \mathrm{L} \mathrm{NaOH}$ & 13.5 \\
8 & & $0.6 \mathrm{~mol} / \mathrm{L} \mathrm{NaOH}$ & 13.8 \\
9 & 1.50 & Distilled water & 7.0 \\
10 & & $0.1 \mathrm{~mol} / \mathrm{L} \mathrm{NaOH}$ & 13.0 \\
11 & & $0.3 \mathrm{~mol} / \mathrm{L} \mathrm{NaOH}$ & 13.5 \\
12 & & $0.6 \mathrm{~mol} / \mathrm{L} \mathrm{NaOH}$ & 13.8 \\
& & & \\
\hline
\end{tabular}

applied at the two ends of the specimen and $(\Delta Q / \Delta t)$ is the flow rate.

An AutoPore IV 9510 Automatic Mercury Porosimeter was used in MIP tests. The specimens tested had different initial dry densities $\left(1.50 \mathrm{mg} / \mathrm{m}^{3}\right.$ and $1.70 \mathrm{mg} / \mathrm{m}^{3}$, respectively) and were infiltrated with $\mathrm{NaOH}$ solution at a concentration of $0.6 \mathrm{~mol} / \mathrm{L}$. The change in surface properties of the specimens was observed with SEM, and the results were used to analyze the influence of highly alkaline solution on the swelling potential, the permeability and the porosity of bentonite. SEM-EDX was used to investigate the change in the Mg content of specimens (montmorillonite is the only Mg-bearing mineral) in order to assess the effect of highly alkaline pore-water at a microscopic level.

\section{RESULTS AND DISCUSSIONS}

\section{Swelling pressure and hydraulic conductivity}

The swelling pressure $v s$. the concentration of alkaline solutions is shown in Fig. 2. The greater the $\mathrm{NaOH}$ concentration the lower the swelling pressure. The curves show two maxima. In the first stage, the swelling pressure increases rapidly to a first maximum. After a reduction phase of $\sim 10-15 \mathrm{~h}$, the swelling pressure increases again to its final steady state. The second rate of increase is much smaller than that in the first stage. At a given initial dry density the swelling pressure decreased with increasing alkaline concentration (Fig. 2). This observation confirms previous studies of the alkaline alteration of GMZ bentonite which reported loss of swelling capacity of the bentonite, due to the reaction of smectites and cristobalite with alkali solutions including possibly the increase in $\mathrm{Na}$ concentration in the interlayer (Lehikoinen et al., 1996; Nakayama et al., 2004; Karnland et al., 2007; Yamaguchi et al., 2007).

The influence of alkaline solutions on swelling pressure depends on the initial dry density which increases from $0 \mathrm{~mol} / \mathrm{L}$ (distilled water) to $0.6 \mathrm{~mol} / \mathrm{L}$ (Fig. 3). The swelling pressure of 1.70/1.60/1.50 mg/m $\mathrm{m}^{3}$ specimens decreases from $4.43 \mathrm{MPa}$ to $3.10 \mathrm{MPa} /$ $3.30 \mathrm{MPa}$ to $1.59 \mathrm{MPa} / 2.02 \mathrm{MPa}$ and finally to $1.18 \mathrm{MPa}$. For a given alkaline concentration, the final swelling pressure increases with increase in dry density.

As mentioned previously, the water pressure increased in steps of $1 \mathrm{kPa}$. This process lasted for $<48 \mathrm{~h}$. The flow rate of the solution decreased over time, and became stable after $\sim 100 \mathrm{~h}$, indicating the full saturation of the specimen. The steady flow rate $(\Delta Q / \Delta t)$ increased with the increase in alkaline concentration. Based on equation 1, the hydraulic conductivity was determined and the results are shown in Table 3.

For a given dry density, the hydraulic conductivity increased steadily with increasing alkaline concentration. According to Villar (2006), the overall sizes of the pipelines between the soil particles increase with infiltration of alkaline solution, resulting in an increase in hydraulic conductivity. It is suggested that the increase in hydraulic conductivity upon reaction with a highly alkaline solution might result at least partly from the dissolution of montmorillonite and cristobalite in GMZ bentonite, damaging the T-O-T structure of montmorillonite (Karnland et al. 2007).

\section{Microstructure, using MIP, of GMZ bentonite after infiltration of alkaline solution}

Compacted bentonite specimens at dry densities of $1.50 \mathrm{mg} / \mathrm{m}^{3}$ and $1.70 \mathrm{mg} / \mathrm{m}^{3}$ and altered at different alkaline concentrations were selected for MIP testing. The pore volume and pore-size distribution are shown in Figs 4a and 4b, respectively. The curves are bimodal, with micro and macro-pores separated at $\sim 150 \mathrm{~nm}$. The macro-pores range in diameter from $300 \mathrm{~nm}$ to $1500 \mathrm{~nm}$, while the micro-pores are mainly $\sim 20 \mathrm{~nm}$. Note that pores of $<5 \mathrm{~nm}$ in diameter are below the detection limit of the instrument. The results are listed in Table 4. 

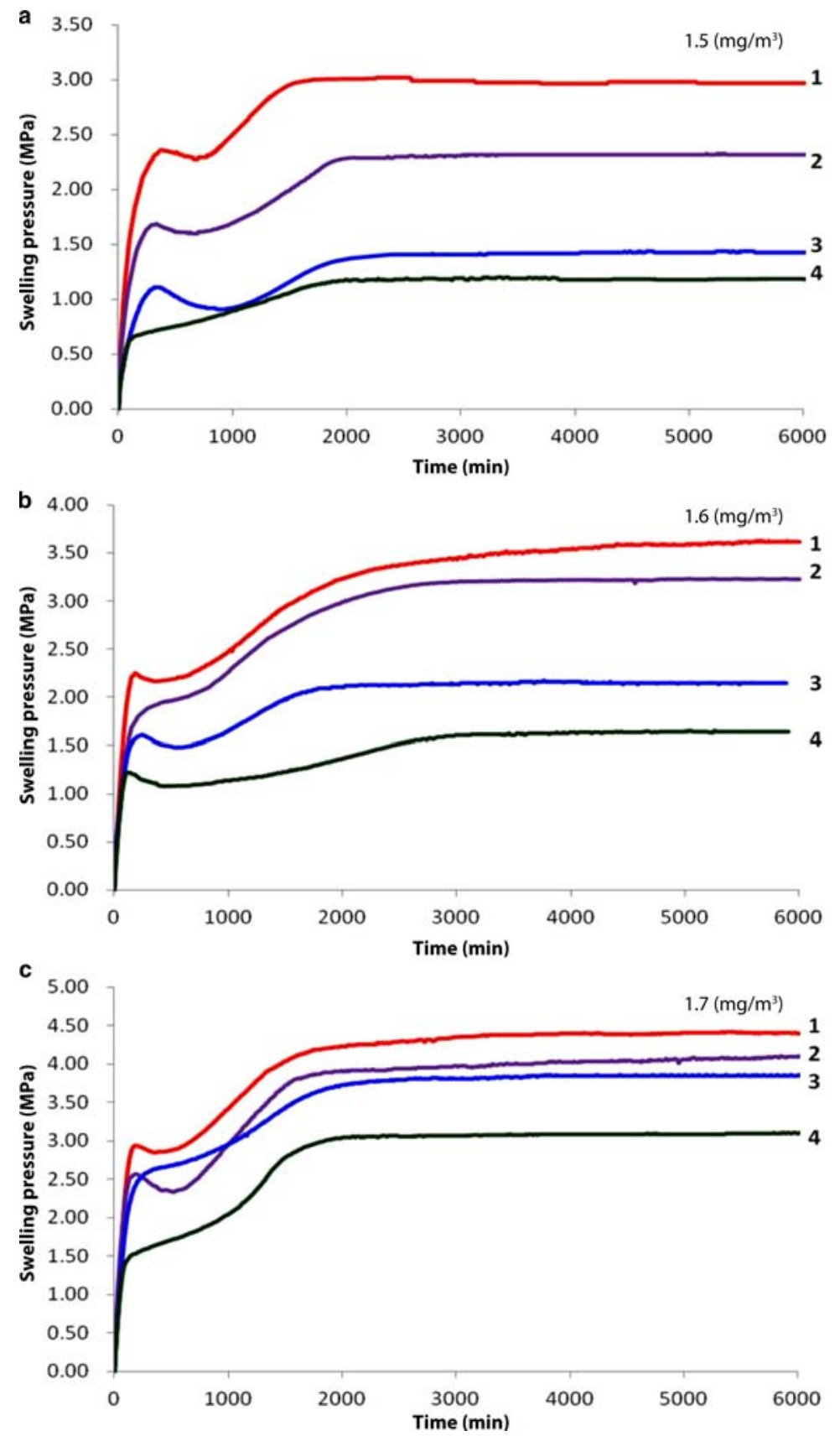

FIG. 2. Swelling-pressure evolution of samples with dry density: (a) $1.50 \mathrm{mg} / \mathrm{m}^{3}$; (b) $1.60 \mathrm{mg} / \mathrm{m}^{3}$; and (c) $1.70 \mathrm{mg} / \mathrm{m}^{3}$ at $\mathrm{NaOH}$ solution concentrations: [1] $0 \mathrm{~mol} \mathrm{~L}^{-1}$, [2] $0.1 \mathrm{~mol} \mathrm{~L}^{-1}$, [3] $0.3 \mathrm{~mol} \mathrm{~L}^{-1}$, [4] $0.6 \mathrm{~mol} \mathrm{~L}^{-1}$.

Comparison between the as-received compacted sample and the sample infiltrated by distilled water shows that the greater the density, the smaller the macro-pore peak value. The macro-pores of the sample of $1.70 \mathrm{mg} / \mathrm{m}^{3}$ dry density are smaller than those of the sample with $1.50 \mathrm{mg} / \mathrm{m}^{3}$ dry density, while the micro-pore sizes are comparable for the two dry densities. 


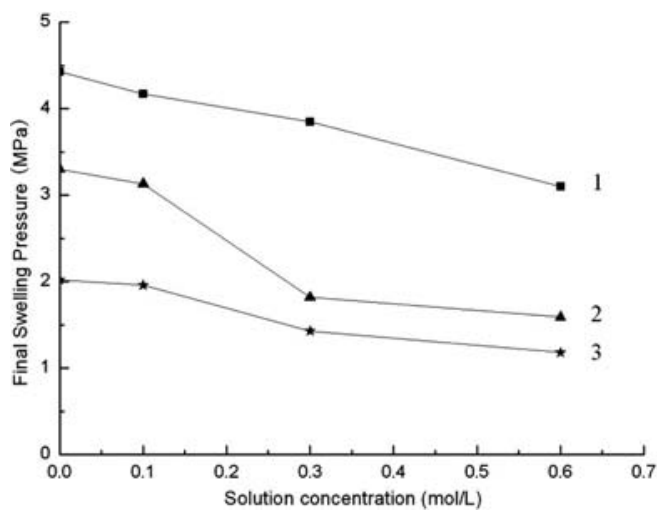

FIG. 3. Evolution of the final swelling pressure with alkaline concentration of samples with different dry densities: [1] $1.70 \mathrm{mg} / \mathrm{m}^{3} ;$ [2] $1.60 \mathrm{mg} / \mathrm{m}^{3} ;$ [3] $1.50 \mathrm{mg} / \mathrm{m}^{3}$.

For the samples altered by different alkaline solutions, changes in macro- and micro-pore peaks were not observed. Only some slight changes were identified in the low dry density of $1.50 \mathrm{mg} / \mathrm{m}^{3}$, suggesting that the greater the dry density, the lower the impact of alkaline solution on the soil microstructure.

When comparing the as-received compacted sample with the sample infiltrated with distilled water at the same dry density, the macro-pores of the sample infiltrated by distilled water decrease significantly, whereas the micro-pores increase. Infiltration of distilled water shifted the macro-pore peak position to a smaller pore size without changing the position of the micro-pore peak. The macro-pores were transformed gradually to smaller pores with distilled water permeation, because bentonite cannot swell under constant-volume conditions.

Comparison of the sample in contact with distilled water with the sample in contact with $\mathrm{NaOH}$ solution shows that after alteration by the alkaline solution, the peaks of both macro- and micro-pores increased. With $\mathrm{NaOH}$ solution, the macro-pore peak shifted to larger sizes and the micro-pore peak shifted slightly to smaller sizes. The volumes of both macro- and micropores increased also, with more evident increase in the macro-pores (see Figs $4 \mathrm{a}$ and $4 \mathrm{~b}$ ). This can be explained by assuming that the bentonite reaction with alkaline solution generated colloidal particles of hydrated calcium silicate gel $(\mathrm{CSH})$, clogging the micro-pores and leading to larger sizes for the smallpore peak (Cuisinier et al., 2008). The increase in macro-pore size can be explained by the decrease in diffuse double layer and the partial dissolution of montmorillonite.
TABLE 3. Hydraulic conductivity of compacted GMZ bentonite under different experimental conditions.

\begin{tabular}{lll}
\hline $\begin{array}{l}\text { Dry } \\
\text { density } \\
\left(\mathrm{mg} \mathrm{m}^{-3}\right)\end{array}$ & Solution & $\begin{array}{l}\text { Hydraulic } \\
\text { conductivity } \\
\left(10^{-13} \mathrm{~m} / \mathrm{s}\right)\end{array}$ \\
\hline 1.70 & Distilled water & 2.23 \\
& $0.1 \mathrm{~mol} / \mathrm{L} \mathrm{NaOH}$ & 2.56 \\
& $0.3 \mathrm{~mol} / \mathrm{L} \mathrm{NaOH}$ & 3.68 \\
& $0.6 \mathrm{~mol} / \mathrm{L} \mathrm{NaOH}$ & 4.90 \\
1.60 & Distilled water & 5.69 \\
& $0.1 \mathrm{~mol} / \mathrm{L} \mathrm{NaOH}$ & 6.31 \\
& $0.3 \mathrm{~mol} / \mathrm{L} \mathrm{NaOH}$ & 8.01 \\
& $0.6 \mathrm{~mol} / \mathrm{L} \mathrm{NaOH}$ & 8.76 \\
1.50 & Distilled water & 11.01 \\
& $0.1 \mathrm{~mol} / \mathrm{L} \mathrm{NaOH}$ & 12.67 \\
& $0.3 \mathrm{~mol} / \mathrm{L} \mathrm{NaOH}$ & 14.20 \\
& $0.6 \mathrm{~mol} / \mathrm{L} \mathrm{NaOH}$ & 15.33 \\
\hline
\end{tabular}

The cumulative pore-size distribution curves of samples $\mathrm{A} 1, \mathrm{~A} 2$ and $\mathrm{A} 3$ and $\mathrm{B} 1, \mathrm{~B} 2$ and $\mathrm{B} 3$ are shown in Fig. 5. The cumulative injection pore volumes of samples A1, A2 and A3 are $0.261 \mathrm{~mL} / \mathrm{g}, 0.109 \mathrm{~mL} / \mathrm{g}$ and $0.155 \mathrm{~mL} / \mathrm{g}$, respectively, and those of samples B1, $\mathrm{B} 2$ and $\mathrm{B} 3$ are $0.176 \mathrm{~mL} / \mathrm{g}, 0.103 \mathrm{~mL} / \mathrm{g}$ and $0.133 \mathrm{~mL} / \mathrm{g}$, respectively. The void ratio $e$ can be deduced by:

$$
e=V_{\mathrm{ci}} \cdot G_{\mathrm{s}}
$$

where $V_{\mathrm{ci}}$ is the cumulative injection pore volume and $G_{\mathrm{s}}$ is the specific gravity, equal to 2.66 for GMZ bentonite. For samples A1, A2 and A3, the void ratios are 0.694, 0.290 and 0.412 , respectively, and for samples B1, B2 and $\mathrm{B} 3$, the void ratios are $0.468,0.274$ and 0.354 , respectively.

Comparison of the samples with different dry densities shows that the greater the dry density, the smaller the pore size. In addition, the influence of infiltration of alkaline solution on the void ratio is small. When comparing the as-received compacted sample with the sample infiltrated by distilled water, the bentonite swelling under constant volume conditions decreased the pore volume. As a result, the porosity of the as-received compacted sample was greater than that infiltrated by distilled water. Finally, comparison between the samples infiltrated by distilled water and alkaline solution shows that alkaline solution infiltration increased the void ratio, thus increasing the hydraulic conductivity. From a practical point of view, this will reduce buffer performance. 

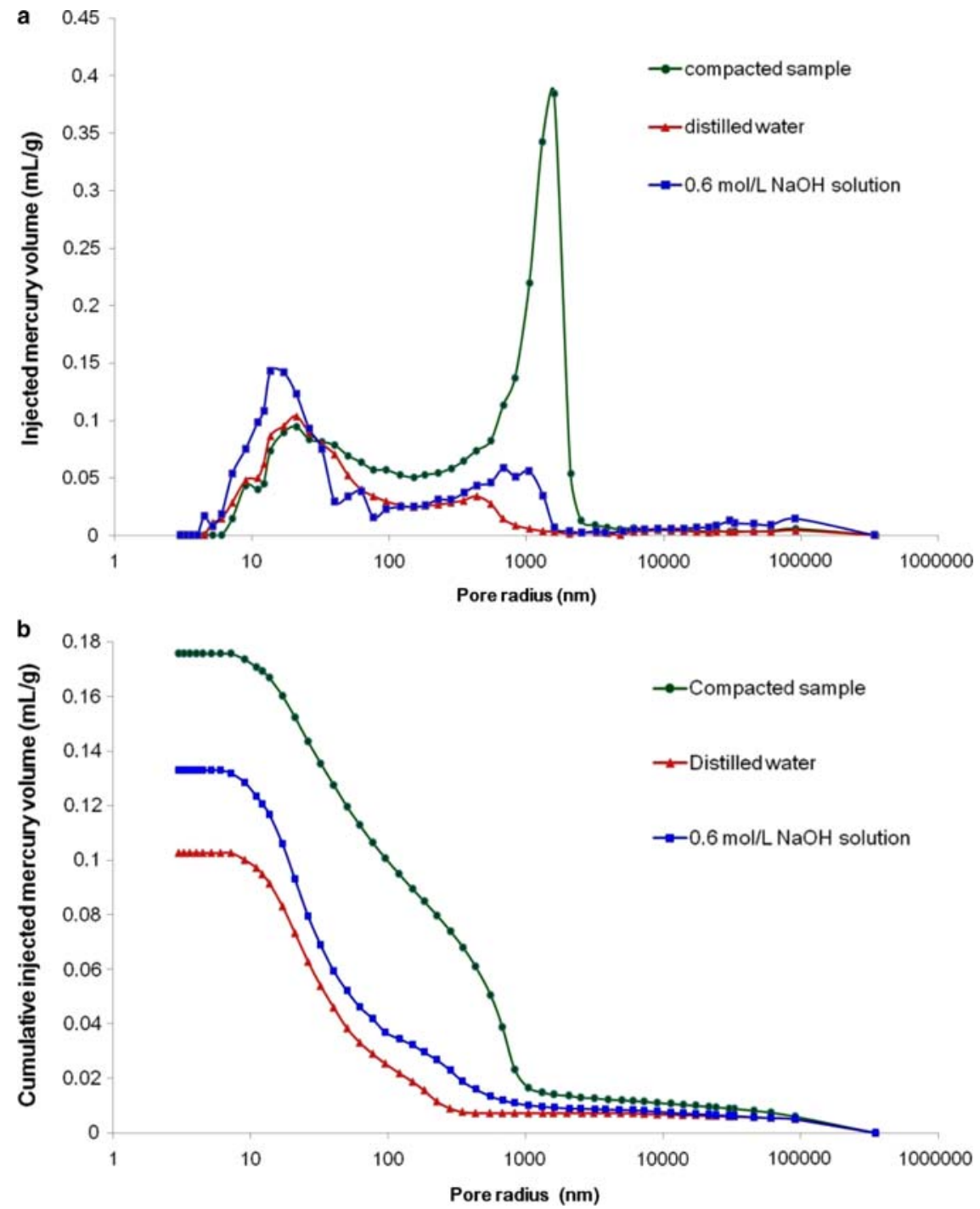

FIG. 4. Pore-size distribution curves of samples at (a) $1.50 \mathrm{mg} / \mathrm{m}^{3}$ and (b) $1.70 \mathrm{mg} / \mathrm{m}^{3}$ dry density.

\section{Microstructure by SEM}

Scanning electron microscopy allowed identification of the effect of alkaline solution on the surface morphology of the samples. In order to limit the poresize change due to sample preparation, freeze-drying was carried out. A fresh broken surface of the sample, exposed using a knife, was examined by means of SEM. Representative photomicrographs of samples $1-4$ with a dry density of $1.70 \mathrm{mg} / \mathrm{m}^{3}$ are shown in Fig. 6. After contact with distilled water, the structure of montmorillonite was essentially unchanged (Fig. 6a). Some wing-shaped colloidal particles exist on the surface and surface cracks, and large pores are scarcely observed, in accordance with the MIP results. After reaction with the alkaline solution, the wingshaped colloidal particles on the surface seem to have dissolved and cracks and small particles of montmorillonite appear (Fig. 6b). Large flakes are the main crystalline form of montmorillonite; the surface was more altered and the number of small fragments of montmorillonite increased significantly (Fig. 6c). 

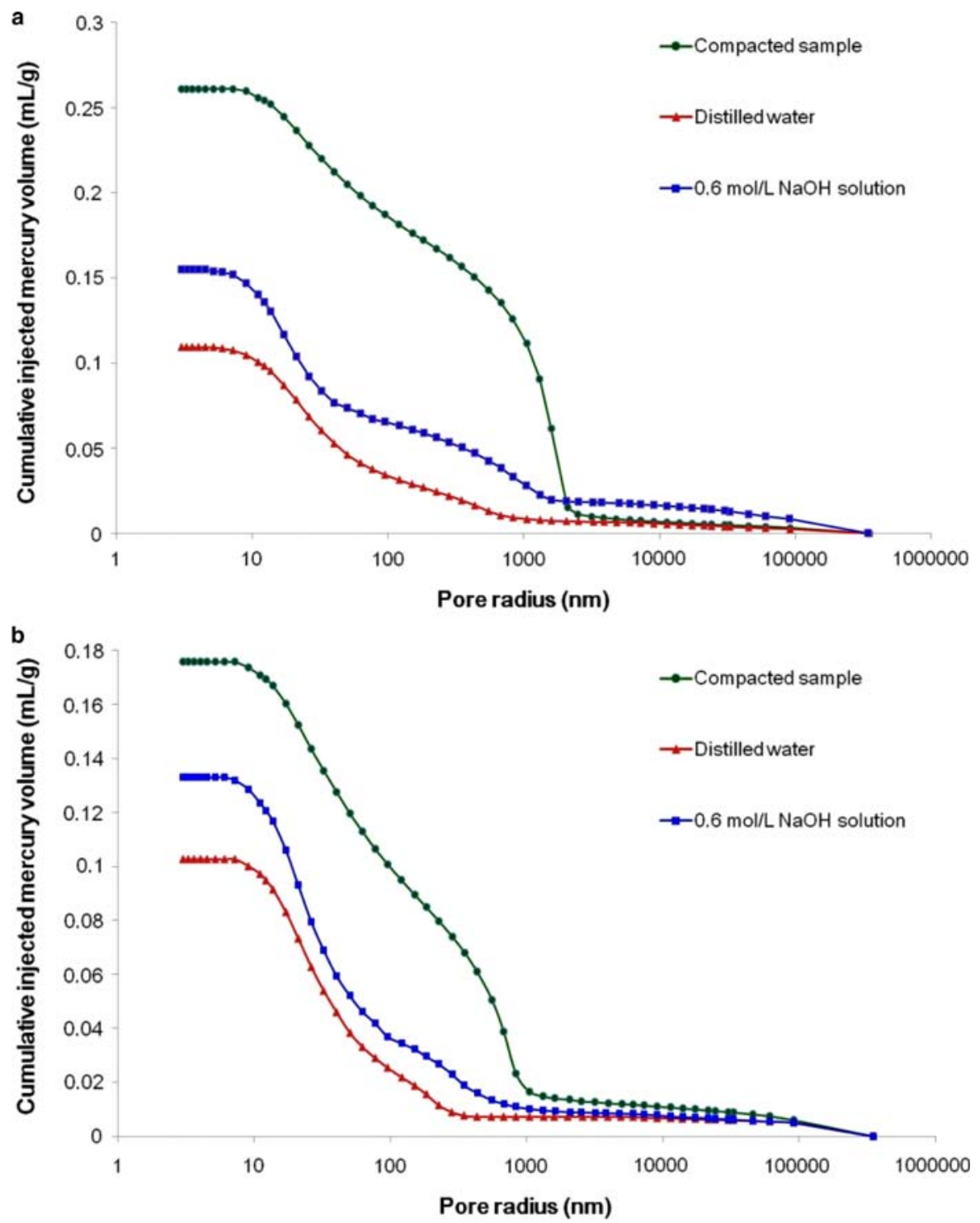

FIG. 5. Cumulative pore-size distribution curves of samples at (a) $1.50 \mathrm{~g} / \mathrm{m}^{3}$ and (b) $1.70 \mathrm{mg} / \mathrm{m}^{3}$ dry density.

Cracks in montmorillonite aggregates and fragmentation and formation of small ensembles were also observed (Fig. 6d).

The hydration of montmorillonite yielded wingshaped colloidal crystallites on the surfaces of samples, clogging of pores and reducing soil porosity and hydraulic conductivity, in agreement with the MIP results. After alteration by alkaline solution, montmorillonite was probably dissolved, the sample surface cracked, and small montmorillonite particles gradually formed. This is consistent with changes in swelling pressure, hydraulic conductivity and total porosity.

\section{Mineralogy}

Major components of GMZ bentonite are montmorillonite, quartz, cristobalite, plagioclase and microcline (Table 1). Montmorillonite is the only Mg-bearing mineral. Although SEM-EDX analysis is semi-quantitative, the intensity of the $\mathrm{Mg}$ peak may provide 
TABLE 4. Peak values of pore-size distribution curves.

\begin{tabular}{lclllll}
\hline No. & Dry density $\left(\mathrm{mg} / \mathrm{m}^{3}\right)$ & Solution & $V_{\mathrm{p}}(\mathrm{mL} / \mathrm{g})$ & $r_{\mathrm{p}}(\mathrm{nm})$ & $V_{\mathrm{p}}(\mathrm{mL} / \mathrm{g})$ & $r_{\mathrm{p}}(\mathrm{nm})$ \\
\hline A1 & \multirow{2}{*}{1.50} & As-compacted state powder & 0.384 & 1595.580 & 0.095 & 21.066 \\
A2 & & Distilled water & 0.034 & 434.056 & 0.104 & 21.066 \\
A3 & \multirow{2}{*}{1.70} & 0.6 mol/L NaOH & 0.056 & 677.810 & 0.143 & 13.718 \\
B1 & As-compacted state powder & 0.173 & 675.859 & 0.093 & 21.066 \\
B2 & & Distilled water & 0.044 & 183.014 & 0.109 & 21.066 \\
B3 & & 0.6 mol/L NaOH & 0.046 & 283.304 & 0.143 & 17.086 \\
& & & & & \\
\hline
\end{tabular}

$V_{\mathrm{p}}$ is the volume of macro-pores, $r_{\mathrm{p}}$ is the average radius of macro-pores, $V_{\mathrm{p}}$ is the volume of micro-pores, $r_{\mathrm{p}}$ is the average radius of micro-pores.

information about the variation of montmorillonite content upon alteration by different alkaline concentrations at the microscale (Fig. 7). The Mg intensity decreased with increasing alkaline concentration suggesting a smaller montmorillonite content possibly due to dissolution.
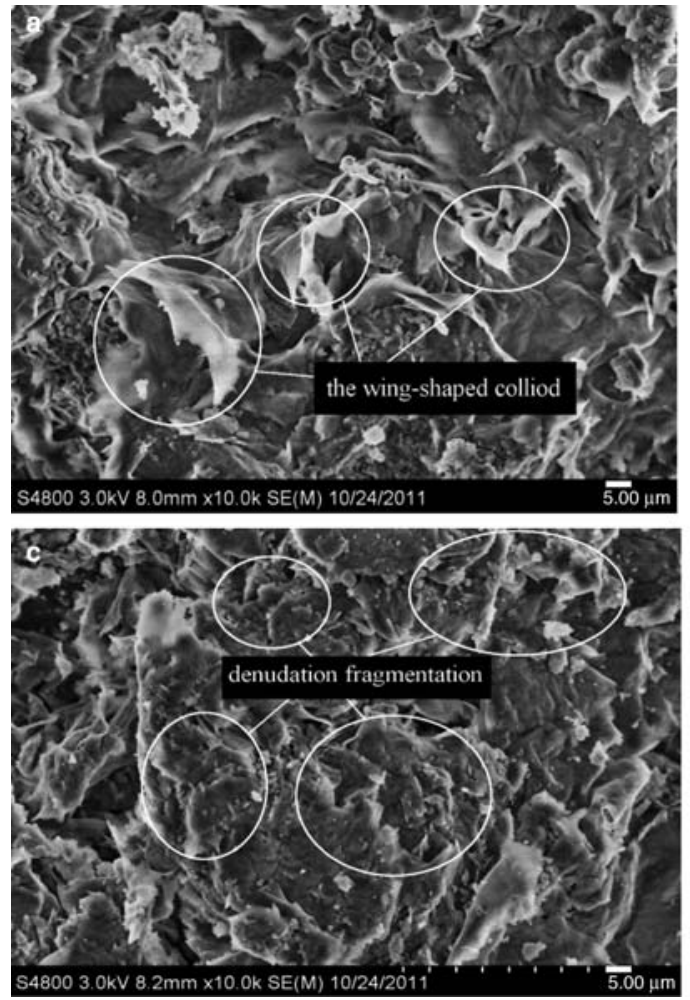

\section{SUMMARY AND CONCLUSIONS}

A multi-functional swelling permeameter was used to conduct tests on the infiltration of highly alkaline solutions in compacted GMZ bentonite. The changes in microstructure and mineralogy under the effect of

FIG. 6. SEM images of specimens at dry density of $1.70 \mathrm{~g} / \mathrm{m}^{3}$ subjected to infiltration of different solutions: (a) distilled water; (b-d) $\mathrm{NaOH}$ solution with concentrations of $0.1 \mathrm{~mol} / \mathrm{L}, 0.3 \mathrm{~mol} / \mathrm{L}$ and $0.6 \mathrm{~mol} / \mathrm{L}$. 


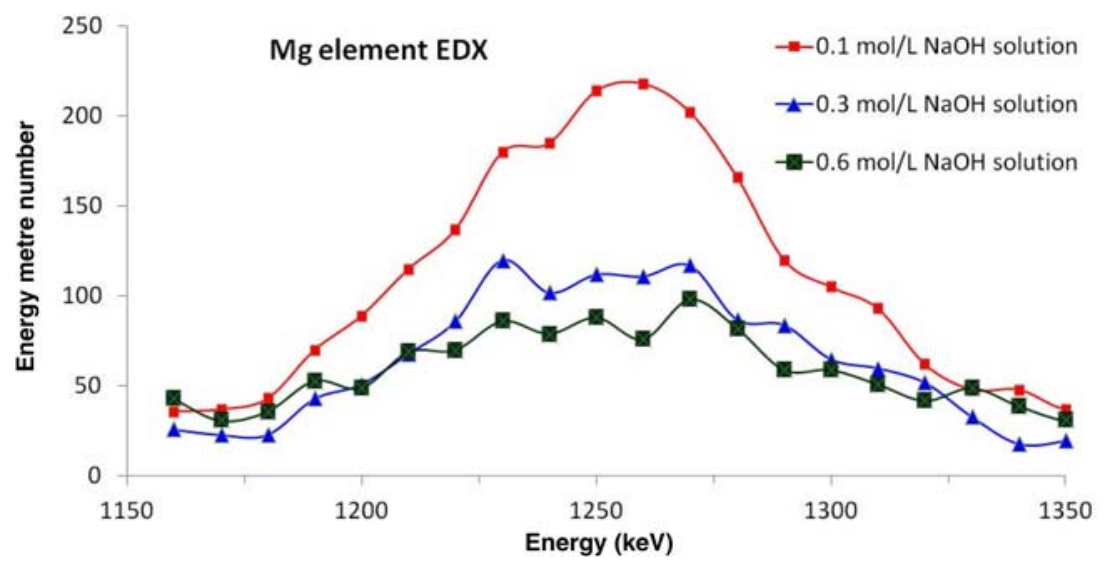

FIG. 7. EDX intensities of $\mathrm{Mg}$ of three samples subjected to different alkaline solution infiltration.

alkaline solutions were also investigated. The results yielded the following conclusions:

After infiltration of highly alkaline solutions, the swelling pressure of bentonite decreased and the permeability increased. The swelling of bentonite is mainly due to the hydration of montmorillonite. At a given dry density, the greater the alkaline concentration, the less obvious the double-peak changes of swelling pressure. Montmorillonite and cristobalite might have dissolved after reaction with the alkaline solution, contributing to the reduction of swelling pressure and the increase in hydraulic conductivity. The greater the alkaline concentration, the greater the changes in swelling pressure and hydraulic conductivity. The decrease in thickness of the diffuse ionic double layer might also explain the decrease in swelling pressure and the increase in hydraulic conductivity.

The pore-size distribution curves were bimodal, the boundary of macro- and micro-pores being at $\sim 150 \mathrm{~nm}$. The initial dry density of the sample affected the macropores to a significant extent, but had limited influence on the micropores. Compared with the initial state, the average porosity of GMZ bentonite after hydration decreased, due to the decrease in the macropore volume. After infiltration of the alkaline solution, the porosity and the pore size increased, the macro-pore size in particular. The greater the dry density, the greater the influence of alkaline solution on the microstructure.

Montmorillonite has a lamellar structure. With infiltration of distilled water, wing-shaped colloids at the lamellar montmorillonite surface might have formed, which might have clogged the pores under constant-volume conditions, decreasing the hydraulic conductivity. Highly alkaline solution may cause dissolution and fragmentation of montmorillonite, thereby increasing the pore size, and thus the hydraulic conductivity. Future studies of GMZ bentonite should include mineralogical analysis to understand the mechanisms observed in the present study.

\section{ACKNOWLEDGEMENTS}

This study was supported financially by the National Science Foundation of China (41372270).

\section{REFERENCES}

Anderson K., Allard B. \& Bengtsson M. (1989) Chemical composition of cement pore solutions. Cement and Concrete Research, 19, 327-332.

Berner U.R. (1992) Evolution of pore-water chemistry during degradation of cement in a radioactive waste repository environment. Waste Management, 12, 201-219.

Cuisinier O., Masrouri F. \& Pelletier M. (2008) Microstructure of a compacted soil submitted to an alkaline plume. Applied Clay Science, 40, 159-170.

Deneele D., Cuisinier O. \& Hallaire V. (2010) Micostructural evolution and physico-chemical behavior of compacted clayey soil submitted to an alkaline plume. Journal of Rock Mechanics and Geotechnical Engineering, 2, 169-177.

Glasser F.P. \& McCulloch C. (1988) Characterization of radioactive waste forms. Commission of the European Communities, Luxembourg, pp. 107-125.

Guo Y.H., Wang J. \& Lu C.H. (2005) Chemical characteristics of groundwater and water-rock interaction: modeling of Yemaquan preselected area for 
China's high level radioactive waste repository. Earth Science Frontiers, 12, 117-123 (in Chinese).

Herbert H., Kasbohm J. \& Sprenger H. (2008) Swelling pressures of MX- 80 bentonite in solutions of different ionic strength. Physics and Chemistry of the Earth, A/ $B / C, \mathbf{3 3}, 327-342$.

Karnland O., Olsson S. \& Nilsson U. (2007) Experimentally determined swelling pressures and geochemical interactions of compacted Wyoming bentonite with highly alkaline solutions. Physics and Chemistry of the Earth, 32, 275-286.

Lehikoinen J., Carlsson T. \& Muurinen A. (1996) Evaluation of factors affecting diffusion in compacted bentonite. Materials Research Society Proceedings. Materials Research Society, Pittsburgh, USA, pp. 675-682.

Liu Y.M. \& Wen Z.J. (2003) Study on clay materials used in a high level radioactive waste repository. Journal of Mineralogy and Petrology, 23, 42-45 (in Chinese).

Nakayama S., Sakamoto Y. \& Yamaguchi T. (2004) Dissolution of montmorillonite in compacted bentonite by highly alkaline aqueous solutions and diffusivity of hydroxide ions. Applied Clay Science, 27, 53-65.

Qian L.X. (2007) A fundamental study of GMZ bentonite as buffer material in deep geological disposal for high-level radioactive waste. $\mathrm{PhD}$ thesis, Tongji University, China (in Chinese).

Ramírez S., Cuevas J. \& Vigil R. (2002) Hydrothermal alteration of 'La Serrata' bentonite (Almería Spain) by alkaline solutions. Applied Clay Science, 21, 257-269.

Ramírez S., Vieillarda P. \& Bouchetc A. (2005) Alteration of the Callovo-Oxfordian clay from Meuse-Haute Marne underground laboratory (France) by alkaline solution. I. A XRD and CEC study. Applied Geochemistry, 20, 89-99.

Read D., Glasser F.P. \& Ayora C. (2001) Mineralogical and microstructural changes accompanying the interaction of Boom Clay with ordinary Portland cement. Advances in Cement Research, 13, 175-183.

Sánchez L., Cuevas J. \& Ramírez S. (2006) Reaction kinetics of FEBEX bentonite in hyperalkaline conditions resembling the cement-bentonite interface. Applied Clay Science, 33, 125-141.

Savage D., Noy D. \& Mihara M. (2002) Modelling the interaction of bentonite with hyperalkaline fluids. Applied Geochemistry, 17, 207-223.

Savage D., Walker C. \& Arthur R. (2007) Alteration of bentonite by hyperalkaline fluids: A review of the role of secondary minerals. Physics and Chemistry of the Earth, 32, 287-297.

Vigil R., Cuevas J., Ramírez S. (2001) Zeolite formation during the alkaline reaction of bentonite. European Journal of Mineralogy, 13, 635-644.

Villar M.V. (2006) Infiltration tests on a granite/bentonite mixture: Influence of water salinity. Applied Clay Science, 31, 96-109.

Wen Z.J. (2006) Physical property of China's buffer material for high-level radioactive waste repositories. Chinese Journal of Rock Mechanics and Engineering, 25, 794-800.

Yamaguchi T., Sakamoto Y. \& Akai M. (2007) Experimental and modeling study on long-term alteration of compacted bentonite with alkaline groundwater. Physics and Chemistry of the Earth, 32, 298-310.

Ye W.M., Qian L.X. \& Chen B. (2009) Characteristics of micro-structure of densely compacted Gaomiaozi bentonite. Journal of Tongji University (Natural Science), 37, 31-35 (in Chinese).

Ye W.M., Chen Y.G. \& Chen B. (2010) Advances on the knowledge of the buffer/backfill properties of heavilycompacted GMZ bentonite. Engineering Geology, 116, 12-20. 